\title{
Effect of Cediranib, Temozolamide and Radiotherapy in U87 GBM wtEGFR and EGFRvIll-expressing Xenografts
}

\author{
P. Wachsberger \\ Thomas Jefferson University Hospitals \\ R. Y, Lawrence \\ Thomas Jefferson University Hospitals \\ Y. Liu \\ Thomas Jefferson University Hospitals \\ B. Andersen \\ Thomas Jefferson University Hospitals
}

A. P. Dicker

Ihomas Jefferson University Hospitals

follow this and additional works at: https://jdc.jefferson.edu/bodinejournal

Part of the Oncology Commons

Let us know how access to this document benefits you

\section{Recommended Citation}

Wachsberger, P.; Lawrence, R. Y; Liu, Y.; Andersen, B.; and Dicker, A. P. (2010) "Effect of Cediranib, Temozolamide and Radiotherapy in U87 GBM wtEGFR and EGFRvIll-expressing Xenografts," Bodine Journal: Vol. 3 : Iss. 1 , Article 21.

DOI: https://doi.org/10.29046/TBJ.003.1.020

Available at: https://jdc.jefferson.edu/bodinejournal/vol3/iss1/21

This Article is brought to you for free and open access by the Jefferson Digital Commons. The Jefferson Digital Commons is a service of Thomas Jefferson University's Center for Teaching and Learning (CTL). The Commons is a showcase for Jefferson books and journals, peer-reviewed scholarly publications, unique historical collections from the University archives, and teaching tools. The Jefferson Digital Commons allows researchers and interested readers anywhere in the world to learn about and keep up to date with Jefferson scholarship. This article has been accepted for inclusion in Bodine Journal by an authorized administrator of the Jefferson Digital Commons. For more information, please contact: JeffersonDigitalCommons@jefferson.edu. 


\section{Effect of Cediranib, Temozolamide and Radiotherapy in U87 GBM wtEGFR and EGFRvIll-expressing Xenografts}

Wachsberger, P., Lawrence, R.Y., Liu, Y., Andersen, B., Dicker, A.P.

Department of Radiation Oncology, Thomas Jefferson University Hospitals, Philadelphia, PA

\section{Introduction}

Glioblastomas (GBM) frequently overexpress the epidermal growth factor receptor (wtEGFR) or its mutant, EGFRvIII contributing to radioresistance. New treatment strategies for GBM include blockade of EGFR signaling and angiogenesis. Cediranib (CD) is a highly potent VEGFR-2 RTKI that inhibits all three VEGF receptors. This study investigated the radiosensitizing potential of $\mathrm{CD}$ in combination with temozolamide (TMZ) in U87 GBM xenografts expressing wtEGFR or EGFRvIII.

\section{Method}

U87 GBM cells transfected with wtEGFR or EGFRvIII were injected into the hind limbs of nude mice. CD was dosed at $3 \mathrm{mg} / \mathrm{kg}$ daily (days 0-9); TMZ at $10 \mathrm{mg} / \mathrm{kg}$ on day 0 . Radiotherapy (RT) consisted of 3 fractions of 5 Gy (days 0-2). VEGF was assayed from culture media $48 \mathrm{hr}$ after treatment.

\section{Results}

In U87 EGFRvIII xenografts, RT, CD or TMZ alone significantly increased tumor doubling time $\left(\mathrm{T}_{2 \mathrm{x}}\right)$, when compared to control (4.6, 4.85 and 4.31 for $\mathrm{CD}, \mathrm{RT}$ and TMZ respectively vs. 3.0 for control). $\mathrm{TMZ}+\mathrm{RT}$, but not $\mathrm{CD}+\mathrm{RT}$, was significantly better than RT alone ( $\mathrm{T}_{2 \mathrm{x}}=6.22$ vs. 4.85 respectively). However, $\mathrm{CD}+\mathrm{TMZ}$ was significantly better than TMZ alone $\left(\mathrm{T}_{2 \mathrm{x}}=6.3\right.$ for cediranib $+\mathrm{TMZ}$ vs. 4.3 for TMZ). The triple combination of $\mathrm{CD}$, TMZ and RT was significantly better than RT alone. In U87 wtEGFR xenografts, single agent RT and TMZ were significantly better than control $\left(\mathrm{T}_{2 \mathrm{x}}=7.84\right.$ and 6.72 for RT and TMZ respectively vs. 3.45 for control). Single agent $\mathrm{CD}$ marginally increased $\mathrm{T}_{2 \mathrm{x}}$ compared to control (4.69 vs. 3.45, NS). CD + TMZ was significantly better than TMZ alone $\left(\mathrm{T}_{2 \mathrm{x}}=11.63\right.$ vs. 6.72 respectively). The triple combination of $\mathrm{CD}, \mathrm{TMZ}$ and $\mathrm{RT}$ was marginally better than RT alone but did not reach significance. In cell culture, TMZ, stimulated VEGF secretion from both U87 wtEGFR and U87 EGFRvIII cells; however, VEGF levels were higher from U87 EGFR cells than U87 EGFRvIII cells.

\section{Conclusion}

CD appears to be effective in GBM, both as a single agent and when combined with TMZ. Tumors expressing EGFRvIII were more sensitive than tumors expressing wtEGFR, possibly due to inability of CD to overcome excessive VEGF secretion by the latter.

Support: AstraZeneca Pharmaceuticals and the Radiation Therapy Oncology Group. 